\title{
Casuarina glauca Prenodule Cells Display the Same Differentiation as the Corresponding Nodule Cells
}

\author{
Laurent Laplaze, ${ }^{1}$ Emile Duhoux, ${ }^{1}$ Claudine Franche, ${ }^{1}$ Thierry Frutz, ${ }^{1}$ Sergio Svistoonoff, ${ }^{1}$ \\ Ton Bisseling, ${ }^{2}$ Didier Bogusz, ${ }^{1}$ and Katharina Pawlowski ${ }^{2,3}$ \\ ${ }^{1}$ Physiologie Cellulaire et Moléculaire des Arbres, Laboratoire GeneTrop, IRD, 911 avenue Agropolis, 34032 \\ Montpellier Cedex 01, France; ${ }^{2}$ Department of Molecular Biology, Dreijenlaan 3, Agricultural University, \\ 6703 HA Wageningen, The Netherlands; ${ }^{3}$ Albrecht-von-Haller-Institut für Pflanzenwissenschaften, \\ Biochemie der Pflanze, Universitât Göttingen, Untere Karspüle 2, D-37073 Göttingen, Germany \\ Accepted 24 September 1999.
}

\begin{abstract}
Recent phylogenetic studies have implied that all plants able to enter root nodule symbioses with nitrogen-fixing bacteria go back to a common ancestor (D. E. Soltis, P. S. Soltis, D. R. Morgan, S. M. Swensen, B. C. Mullin, J. M. Dowd, and P. G. Martin, Proc. Natl. Acad. Sci. USA, 92:2647-2651, 1995). However, nodules formed by plants from different groups are distinct in nodule organogenesis and structure. In most groups, nodule organogenesis involves the induction of cortical cell divisions. In legumes these divisions lead to the formation of a nodule primordium, while in non-legumes they lead to the formation of a so-called prenodule consisting of infected and uninfected cells. Nodule primordium formation does not involve prenodule cells, and the function of prenodules is not known. Here, we examine the differentiation of actinorhizal prenodule cells in comparison to nodule cells with regard to both symbionts. Our findings indicate that prenodules represent primitive symbiotic organs whose cell types display the same characteristics as their nodule counterparts. The results are discussed in the context of the evolution of root nodule symbioses.
\end{abstract}

Additional keywords: actinorhiza, Frankia, hemoglobin, nifH, nitrogen fixation, symbiosis.

Through symbiotic association with bacteria, legumes and actinorhizal plants have the unique ability to develop root nodules where $\mathrm{N}_{2}$ is reduced to ammonia. Legumes enter symbioses with rhizobia, while the actinomycete Frankia interacts with a diverse group of angiosperms collectively called actinorhizal plants. These intimate and complex interactions involve symbiosis-specific differentiation of both partners (Hirsch 1992; Pawlowski and Bisseling 1996; Franche et al. 1998b).

Recent phylogenetic studies based on $r b c L$ gene sequence analysis have shown that all plants able to enter a root nodule symbiosis group together in one clade, thus indicating that both symbioses go back to a common ancestor (Soltis et al.

Corresponding author : Emile Duhoux; E-mail: duhoux@mpl.ird.fr

This article is in the public domain and not copyrightable. It may be freely reprinted with customary crediting of the source. The American Phytopathological Society, 2000.
1995). Symbiotic plants are grouped in four subclades out of six in the rosid I clade. Nevertheless, legume and actinorhizal nodules differ in developmental pattern and final structure. Legume nodules (subclade B) originate in the root cortex and have peripheral vascular bundles and infected cells in the central tissue, whereas actinorhizal nodules (subclades A, C, D) exhibit the same origin and structure as lateral roots, that is, they arise from cell divisions in the pericycle and possess a central vascular bundle and cortical infected cells (Pawlowski and Bisseling 1996). Interestingly, nodules of Parasponia spp., the only non-legume infected by rhizobia, structurally resemble actinorhizal nodules (Lancelle and Torrey 1984b) and phylogenetically, Parasponia spp. group with actinorhizal plants of the Rhamnaceae, Rosaceae and Elaeagnaceae families (subclade A; Soltis et al. 1995; Swensen 1996).

In one group of actinorhizal plants (subclade C), encompassing the families of the Betulaceae, Casuarinaceae, and Myricaceae, infection proceeds intracellularly via root hairs (Fig. 1A; Benson and Silvester 1993). Upon infection, Frankia induces cell divisions in the cortex, leading to the formation of a small external protuberance called the prenodule (Figs. 1B and 2A; Angulo Carmona 1974; Callaham and Torrey 1977; Berry and Sunell 1990). Some of its cells become infected by Frankia (Figs. 1B, 2B). But while nodule primordia of legumes (subclade B) originate from mitotically activated cortical cells, actinorhizal nodule primordia do not arise from prenodule cells. During prenodule development, mitotic activity is induced in pericycle cells opposite to a protoxylem pole, giving rise to the actinorhiza nodule lobe primordium (Fig. 1C, D; Angulo Carmona 1974; Callaham and Torrey 1977; Berry and Sunell 1990). Nodule induction on Parasponia (subclade A) by rhizobia follows a similar mechanism, although here the bacteria enter the plant intercellularly, not via root hairs (Lancelle and Torrey 1984a). During intercellular infection of actinorhizal plants of the same subclade, i.e., members of the families Rosaceae, Rhamnaceae, and Elaeagnaceae, no prenodule is formed (Miller and Baker 1985; Racette and Torrey 1989). However, in Ceanothus (Rhamnaceae), infection by Frankia leads to divisions of root cortical cells but the dividing cells are not infected (Berry and Sunell 1990). Subclade D contains actinorhizal Datisca and Coriaria whose infection processes have not yet been studied in detail. Hence, cortical cell divisions in 
response to microsymbiont infection occur in at least three out of four subclades.

Thus, in all root nodule symbioses examined to date, the microsymbiont induces cell divisions and infects the newly formed cells. However, only in legumes do the infected cortical cells proceed with divisions and develop into the nodule primordium. In Parasponia and actinorhizal plants, nodule primordium formation is induced in the root pericycle.

The function of prenodules in nodule induction is not yet understood. We followed the differentiation of Frankia and plant cells in Casuarina glauca (subclade C) prenodules with both cytological and molecular markers. Frankia nifH expression in infected prenodule cells was examined as a marker for bacterial nitrogen fixation. As markers for the differentiation of prenodule cells, the expression of the infection-associated actinorhizal nodulin gene $c g 12$ and the symbiotic hemoglobin gene $c g h b-1 F$ (Gherbi et al. 1997) was analyzed as well as infected cell wall lignification. Furthermore, the activities of the soybean leghemoglobin (lbc3) and Parasponia andersonii hemoglobin gene promoters that retain their cell-specific expression in transgenic Casuarinaceae (Franche et al. 1998a) were examined in prenodules. The results will be discussed in view of the suggested common origin of root nodule symbioses (Soltis et al. 1995).

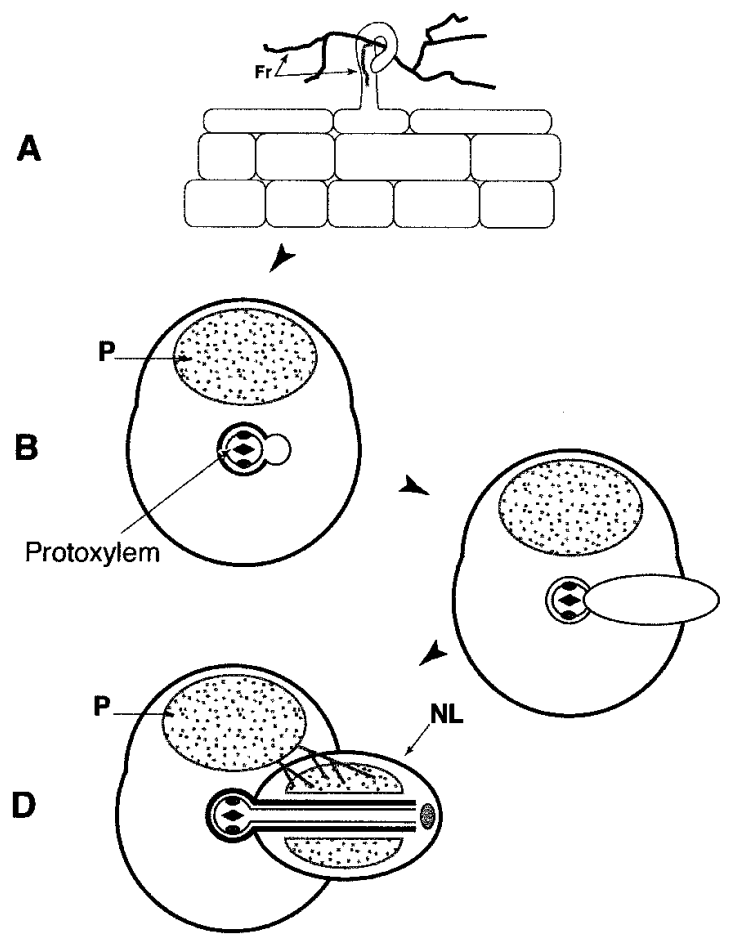

Fig. 1. Intracellular infection and development of a nodule lobe in actinorhizal plants. Schemes of transversal root sections of various developmental stages are shown. A, Frankia hyphae (Fr) progress through a curled root hair. B, Prenodule (P) formation. After infection (5 to 10 days) mitotic activity occurs in cortical cells adjacent to infected root hair; some of these cells become infected by Frankia (gray region). Also, the nodule primordium is initiated in the pericycle opposite to protoxylem poles. C, Development of nodule primordium. Primordium is formed in the root pericycle, and develops into cortical tissue. D, Infection of the nodule primordium. Frankia hyphae coming from the prenodule infect cortical cells at the base of the nodule lobe (NL) primordium and progressively occupy the cortex of the nodule lobe.

\section{RESULTS}

cg12 expression in prenodule infected cells.

In C. glauca and Alnus glutinosa, one marker gene for the differentiation of infected cortical cells of nodules is available. The expression of a serine protease of the subtilase family (cgl2 or ag12, respectively) is strongly induced in nodule cortical cells upon infection by Frankia (Ribeiro et al. 1995; Laplaze et al. 2000). cg12/ag12 expression in infected cells decreases at the onset of bacterial nitrogen fixation. In both plants, the corresponding genes are not expressed in roots but show very low levels of expression in green organs. In situ hybridization showed that $\mathrm{cgl}$ is strongly expressed in prenodule cells where infection proceeds (Fig. 3A, B), the level of expression being similar to that found during infection of cortical cells of the young nodule lobe (Laplaze et al. 2000). A lower signal was also detected in prenodule cells completely filled with Frankia. The same pattern was found for ag12 in prenodules of Alnus glutinosa (data not shown). Thus, cg12/ag12 expression is associated with the infection of plant cells in the same fashion in both nodules and prenodules.
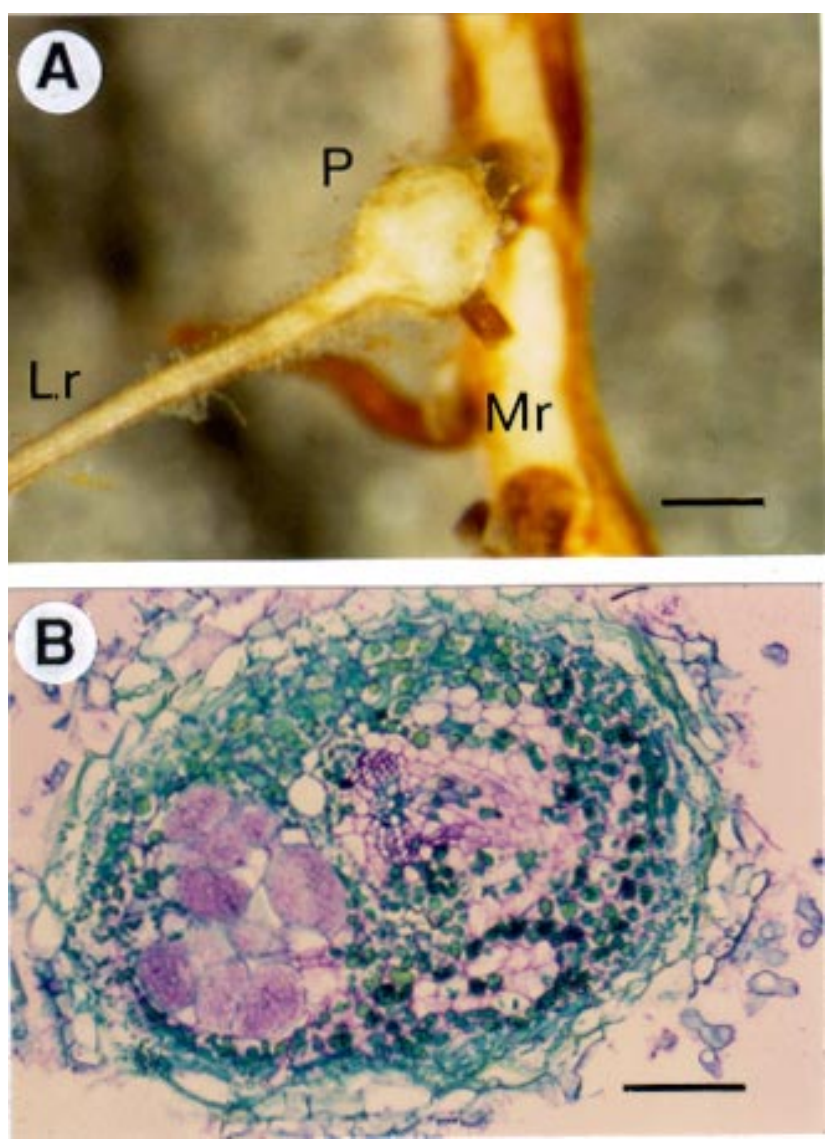

Fig. 2. A, Prenodule on a lateral root of Casuarina glauca. Divisions and enlargement of cortical cells in the proximity of the infected root hair form the prenodule $(\mathrm{P})$, which appears as a small protuberance. $\mathrm{Lr}$, lateral root; Mr, main root. Bar $=500 \mu \mathrm{m}$. B, Transversal section through a lateral root showing a prenodule, stained with toluidine blue. The prenodule consists of large Frankia-infected cells and uninfected cell. Accumulation of phenolics (green color) is observed in response to Frankia infection. Bar $=100 \mu \mathrm{m}$. 

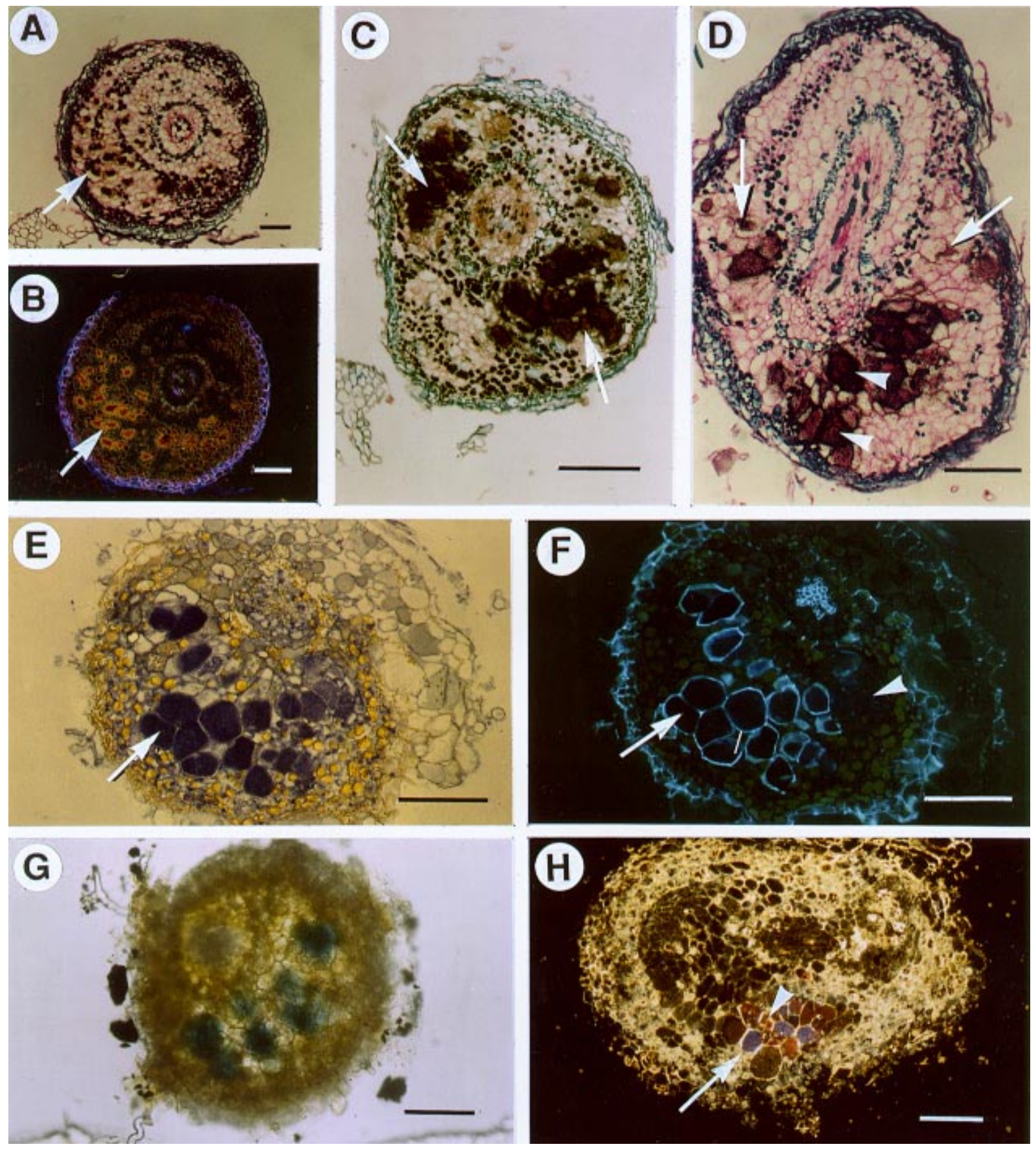

Fig. 3. Analysis of prenodule cell differentiation. A and B, Expression of $c g 12$ in cells of the prenodule (arrows). A, Bright field micrograph; expression is denoted by silver grains appearing as black dots. B, Dark field micrograph taken under fluorescent light; silver grains are visible as orange dots. C, Bright field micrograph of a transversal section of an infected root illustrating Frankia nifH expression as denoted by accumulation of black silver grains in some fully infected prenodule cells (arrows). D, Bright field micrograph of a transversal section of an infected root hybridized with a $C$. glauca symbiotic $h b$ gene probe. High hybridization signal (black silver grains) is found in fully infected prenodule cells (arrowheads); a low signal is found in prenodule cells where infection proceeds (arrows). $\mathbf{E}$ and $\mathbf{F}$, Berberine stain for lignification of cell walls in a transversal section of an infected root. E, Bright field micrograph; fully infected cells (arrows) show strong staining. F, Dark micrograph taken under UV light. Cell walls of fully infected cells are lignified (arrow) whereas cell walls of cells undergoing infection are not lignified (arrowhead). G, Bright field micrograph of a thick, transversal section of a transgenic $A$. verticillata infected root containing the $l b c 3$ promoter GUS ( $\beta$-glucuronidase) fusion. GUS expression is found in some infected cells (blue color) of the prenodule. $\mathbf{H}$, Dark field micrograph of a thick section of a transgenic A. verticillata infected root containing the Parasponia $h b$ promoter GUS fusion. High GUS activity is found in infected prenodule cells (arrows); low activity is found in uninfected prenodule cells (arrowheads). (Bars $=100 \mu \mathrm{m}$ ). 
Nitrogen fixation and oxygen metabolism in prenodules.

In order to achieve symbiosis, both infected plant cells and infecting Frankia hyphae have to undergo a process of differentiation. Expression of nifH, encoding a subunit of the nitrogenase complex, denotes bacterial differentiation for symbiotic nitrogen fixation (Berg and McDowell 1987a; Ribeiro et al. 1995). In C. glauca nodules, nitrogen-fixing infected cells differentiate to provide (i) an oxygen diffusion barrier achieved by lignification of the cell wall (Berg and McDowell 1987b) and (ii) a high amount of the oxygen-transport protein hemoglobin (Jacobsen-Lyon et al. 1995; Gherbi et al. 1997). Frankia nifH and $C$. glauca symbiotic hemoglobin $(h b)$ gene expression was examined by in situ hybridization. nifH was strongly expressed in fully infected prenodule cells (Fig. 3C) while $c g h b$ showed high expression in fully infected prenodule cells and lower expression in cells where infection was in progress (Fig. 3D). Hence, the expression patterns of these two genes were similar to those found in mature $C$. glauca nodules (Gherbi et al. 1997). Moreover, cytological staining with either berberine or phloroglucinol showed that the walls of infected prenodule cells are lignified, suggesting that an oxygen diffusion barrier has been formed (Fig. 3E and F). These data suggest that in the prenodule, Frankia hyphae differentiate into their symbiotic nitrogen-fixing forms and infected plant cells differentiate to support bacterial nitrogen fixation.

\section{The promoters of the symbiotic soybean $(l b c 3)$ and $P$. andersonii $\boldsymbol{h b}$ genes retain cell-specific expression in transgenic Allocasuarina verticillata prenodules.}

We examined the expression of the soybean leghemoglobin gene $l b c 3$ promoter and the $P$. andersonii hemoglobin gene $(h b)$ promoter $\beta$-glucuronidase $(G U S)$ reporter gene constructs in prenodules of transgenic $A$. verticillata, a close relative of C. glauca whose infection pathway is similar to that of $C$. glauca (data not shown). The soybean $l b c 3$ promoter $G U S$ fusion was expressed in large infected cells that were completely filled with Frankia (Fig. 3G). This pattern resembles the one found for $l b c 3$ promoter GUS fusion in nodules of Lotus corniculatus (Stougaard et al. 1987), C. glauca, and A. verticillata (Franche et al. 1998a). The P. andersonii hb promoter GUS fusion was expressed in a similar way in infected prenodule cells and additionally showed low levels of expression in uninfected prenodule cells (Fig. $3 \mathrm{H}$ ). A similar pattern of expression has been reported for the $h b$ gene in $P$. andersonii nodules (Trinick et al. 1989) and for the P. andersonii $h b$ promoter GUS fusion in transgenic $C$. glauca and A. verticillata nodules (Franche et al. 1998a). These data suggest that infected and uninfected prenodule cells contain transcription factors that are also active in the corresponding cells of mature actinorhizal nodules, but not in root cells.

\section{DISCUSSION}

\section{Differentiation of bacterial and plant cells in actinorhizal prenodules.}

During the course of intracellular infection of actinorhizal plants by Frankia and intercellular infection of $P$. andersonii by rhizobia, a prenodule is formed in the nodule cortex before the nodule primordium forms in the pericycle. In intercellularly infected actinorhizal plants, prenodule formation was not observed (Miller and Baker 1985; Racette and Torrey, 1989). No evidence for a specific role of the prenodule has been demonstrated yet.

Our results strongly suggest that Frankia fixes nitrogen in infected prenodule cells of $C$. glauca, as denoted by expression of the nitrogenase structural gene nifH. Similarly, early studies by Angulo Carmona (1974) had shown that the formation of Frankia vesicles in infected cells of A. glutinosa prenodules is associated with a strong reducing power, suggesting bacterial nitrogen fixation. We confirm this hypothesis by showing Frankia nifH expression in vesicles-containing prenodule cells of A. glutinosa (data not shown). Further in situ hybridization studies showed that the expression pattern of the nodule-specific subtilase in prenodule cells resembles that in the corresponding cells of mature nodule lobes in both C. glauca and A. glutinosa (data not shown). Cytological studies provided evidence of lignification of the walls of infected prenodule cells as required for nitrogenase function in C. glauca. Furthermore, studies of hemoglobin promoter-GUS expression in transgenic $A$. verticillata plants suggest that not only infected but also uninfected cells of prenodules display the same features as their counterparts in nodules. The similar differentiation state of uninfected cells from prenodules and nodules is also indicated by the fact that, in contrast to normal root cortical cells, both types of uninfected cells accumulate starch in Comptonia (Callaham and Torrey 1977). Taken together, these observations establish that Frankia-induced root cortical cell divisions lead to the formation of two new cell types displaying the differentiation of infected and uninfected nodule cells. Thus, the prenodule represents a very simple symbiotic organ.

\section{Potential evolutionary significance of actinorhizal prenodules.}

Molecular phylogenetic analysis suggests that all plants entering root nodule symbioses have a common ancestor that had obtained a predisposition for symbiosis (Soltis et al. 1995; Swensen 1996). Thus, legume and actinorhizal nodules may have evolved from a more primitive type of symbiotic organ. This might mean that the formation of prenodule-like structures may have been an early step in the development of root nodule symbiosis. For a highly efficient symbiotic interaction, a connection of the symbiotic organ to the root vascular system would have been needed. The induction of lateral roots at prenodule sites may have occurred to fulfill this requirement and is likely to have led to the evolution of root nodules. The host plant-dependent positioning of the modified lateral root primordium may have led to the differing structures of legume and actinorhizal nodules.

However, it is equally possible that prenodules represent one of the three nodule types that can be formed, and not an evolutionary step toward a more advanced organ. In this case, the ontogeny and tissue composition of nodules are likely to be different from those of prenodules. Yet, our studies have shown that the developmental programs used to produce prenodule cells are also part of the mechanism controlling nodule cell differentiation. Altogether, independent of whether prenodules represent nodule precursors or a parallel development, the similarity of differentiation of prenodule cells with that of their nodule counterparts strongly supports the hypothesis that all plants able to es- 
tablish a root nodule symbiosis arose from a common ancestor predisposed for symbiosis.

\section{MATERIALS AND METHODS}

\section{Plant and bacterial growth conditions.}

C. glauca and A. glutinosa seeds were provided by the Desert Development Center (Cairo) and the Iceland Institute of Technology (Reykjavik, Iceland) respectively. Plants were grown and inoculated as described (Gherbi et al. 1997) with Frankia strains Thr (Girgis et al. 1990) and ArI3 (Berry and Torrey 1979) respectively. Prenodules and nodules were harvested 2 to 4 weeks after inoculation.

\section{Transformation of $A$. verticillata.}

The soybean lbc3-GUS-NOS and P. andersonii hb-GUSNOS constructs were kindly provided by K. Marcker (Lauridsen et al. 1993) and E. Dennis (Bogusz et al. 1990), respectively. Transgenic A. verticillata plants were obtained through the transformation of mature zygotic embryos by engineered Agrobacterium tumefaciens as described previously (Franche et al. 1997). Histochemical localization of GUS activity in A. verticillata prenodules was done as described (Franche et al. 1998a).

\section{Hybridization experiments.}

In situ hybridization experiments were performed as described (Ribeiro et al. 1995). nifH and $h b$ probes were prepared as described by Gherbi et al. (1997). cgl2 probes were prepared by linearization of $\mathrm{pCg} 12$ with SstII and in vitro transcription with T7 RNA polymerase (antisense) or by linearization with PstI and transcription with T3 RNA polymerase (sense). ag 12 probes were prepared as described by Ribeiro et al. (1995).

\section{Histology of cell wall lignification.}

Nodules and prenodules were fixed for $5 \mathrm{~h}$ in $4 \%$ paraformaldehyde, $0.25 \%$ glutaraldehyde, $10 \%$ dimethyl sulfoxide (DMSO), $70 \mathrm{mM}$ ethylene glycol-bis ( $\beta$-aminoethylether)- $N$, $N^{\prime}$-tetraacetic acid (EGTA), and $100 \mathrm{mM}$ phosphate buffer, $\mathrm{pH}$ 7.2, and embedded in melted paraplast or resin (Histo Technik 7100; Labonord, Villeneuve d'Ascq, France). Seven Paraplast $(7 \mu \mathrm{m})$ or resin $(3 \mu \mathrm{m})$ sections were used in the lignification test. Lignified cell walls were stained with berberine (Brundrett et al. 1988) or phloroglucinol.

\section{ACKNOWLEDGMENTS}

We would like to thank S. Swensen (Ithaca College, Ithaca, NY) for helpful discussion. This work was supported by IRD (Institut de Recherche pour le Developpement), K. P. and T. B. also acknowledge support by the Dutch Organization for Scientific Research (NWO).

\section{LITERATURE CITED}

Angulo Carmona, A. F. 1974. La formation des nodules fixateurs d'azote chez Alnus glutinosa (L.). Acta Bot. Neerl. 23:257-303.

Benson, D. R., and Silvester, W. B. 1993. Biology of Frankia strains, actinomycete symbionts of actinorhizal plants. Microbiol. Rev. 57: 293-319.

Berg, R. H., and McDowell, L. 1987a. Endophyte differentiation in
Casuarina actinorhizae. Protoplasma 136:104-117.

Berg, R. H., and McDowell, L. 1987b. Cytochemistry of the wall of infected cells in Casuarina actinorhizae. Can. J. Bot. 66:2038-2047.

Berry, A. M., and Sunell, L. A. 1990. The infection process and nodule development. Pages 61-81 in: The Biology of Frankia and Actinorhizal Plants. C. R. Schwintzer and J. D. Tjepkema, eds. Academic Press, New York.

Berry, A. M., and Torrey, J. G. 1979. Isolation and characterization in vivo and in vitro of an actinomycetous endophyte from Alnus rubra Bong. Pages 69-84 in: Symbiotic Nitrogen Fixation in the Management of Temperate Forests. J. C. Gordon, D. T. Wheeler, and D. A. Perry, eds. Oregon State University Press, Corvallis.

Bogusz, D., Llewellyn, D. J., Craig, S., Dennis, E. S., Appleby, C. A., and Peacock, W. J. 1990. Nonlegume hemoglobin genes retain organspecific expression in heterologous transgenic plants. Plant Cell 2: 633-641.

Brundrett, M. C., Enstone, D. E., and Peterson, C. A. 1988. A berberineaniline blue fluorescent staining procedure for suberin lignin and callose in plant tissue. Protoplasma 146:133-142.

Callaham, D., and Torrey, J. G. 1977. Prenodule formation and primary nodule development in roots of Comptonia (Myricaceae). Can. J. Bot. 55:2306-2318.

Chandler, M. R. 1978. Some observations on infection of Arachis hypogaea L. by Rhizobium. J. Exp. Bot. 29:749-755.

Chandler, M. R., Date, R. A., and Roughley, R. J. 1982. Infection and root-nodule development in Stylosanthes species by Rhizobium. J. Exp. Bot. 33:47-57.

Franche, C., Diouf, D., Laplaze, L., Auguy, F., Frutz, T., Rio, M., Duhoux, E., and Bogusz, D. 1998a. Soybean (Ibc3), Parasponia, and Trema hemoglobin gene promoters retain symbiotic and nonsymbiotic specificity in transgenic Casuarinaceae: Implications for hemoglobin gene evolution and root nodule symbioses. Mol. Plant-Microbe Interact. 11:887-894.

Franche, C., Diouf, D., Le, Q. V., Bogusz, D., N'Diaye, A., Gherbi, H., Gobé, C., and Duhoux, E. 1997. Genetic transformation of the actinorhizal tree Allocasuarina verticillata by Agrobacterium tumefaciens. Plant J. 11:897-904.

Franche, C., Laplaze, L., Duhoux, E., and Bogusz, D. 1998b. Actinorhizal symbioses: Recent advances in plant molecular and genetic transformation studies. Crit. Rev. Plant Sci. 17:1-28.

Gherbi, H., Duhoux, E., Franche, C., Pawlowski, K., Berry, A., Nassar, A., and Bogusz, D. 1997. Cloning of a full-length symbiotic hemoglobin cDNA and in situ localization of the corresponding mRNA in Casuarina glauca root nodule. Physiol. Plant. 99:608-616.

Girgis, Z. G. M., Ishac, Z. Y., El-Haddad, M., Saleh, A. E., Diem, H. G., and Dommergues, R. Y. 1990. First report on isolation and culture of effective Casuarina-compatible strains of Frankia from Egypt. Pages 156-164 in: Advances in Casuarina Research and Utilization. M. H. El-Lakany, J. W. Turnbull, and J. L. Brewbaker, eds. Desert Development Center, A.U.C., Cairo.

Hirsch, A. M. 1992. Developmental biology of legume nodulation. New Phytol. 122:211-237.

Jacobsen-Lyon, K., Ostergaard Jensen, E., Jorgensen, J. E., Marcker, K. A., Peacock, W. J., and Dennis, E. S. 1995. Symbiotic and nonsymbiotic hemoglobin genes of Casuarina glauca. Plant Cell 7:213-223.

Lancelle, S. A., and Torrey, J. G. 1984a. Early development of Rhizobium-induced root nodules of Parasponia rigida. I. Infection and early nodule initiation. Protoplasma 123:26-37.

Lancelle, S. A., and Torrey, J. G. 1984b. Early development of Rhizobium-induced root nodules of Parasponia rigida. II. Nodule morphogenesis and symbiotic development. Can. J. Bot. 63:25-35.

Laplaze, L., Ribeiro, A., Franche, C., Duhoux, E., Auguy, F., Bogusz, D., and Pawlowski, K. 2000. Characterization of a Casuarina glauca nodule-specific subtilisin-like protease gene, a homolog of Alnus glutinosa ag 12. Mol. Plant-Microbe Interact. 13:113-117.

Lauridsen, P., Franssen, H., Stougaard, J., Bisseling, T., and Marcker, K. A. 1993. Conserved regulation of the soybean early nodulin ENOD2 gene promoter in determinate and indeterminate transgenic root nodules. Plant J. 3:483-492.

Miller, I. M., and Baker, D. D. 1985. The initiation, development and structure of root nodules in Elaeagnus angustifolia (Elaeagnaceae). Protoplasma 128:107-119.

Pawlowski, K., and Bisseling, T. 1996. Rhizobial and actinorhizal symbioses: What are the shared features? Plant Cell 8:1899-1913. 
Racette, S., and Torrey, J. G. 1989. Root nodule initiation in Gymnostoma (Casuarinaceae) and Shepherdia (Elaeagnaceae) induced by Frankia strain HFPGpI1. Can. J. Bot. 67:2873-2879.

Ribeiro, A., Akkermans, A. D. L., van Kammen, A., Bisseling, T., and Pawlowski, K. 1995. A nodule-specific gene encoding a subtilisin-like protease is expressed in early stages of actinorhizal nodule development. Plant Cell 7:785-794.

Soltis, D. E., Soltis, P. S., Morgan, D. R., Swensen, S. M., Mullin, B. C., Dowd, J. M., and Martin, P. G. 1995. Chloroplast gene sequence data suggest a single origin of the predisposition for symbiotic nitrogen fixation in angiosperms. Proc. Natl. Acad. Sci. USA 92:2647-2651.
Stougaard, J., Sandal, N. N., Gron, A., Kuhle, A., and Marcker, K. A. 1987. $5^{\prime}$ analysis of the soybean leghemoglobin $l b c-3$ gene regulatory elements required for promoter activity and organ specificity. EMBO J. 6:3565-3569.

Swensen, S. 1996. The evolution of actinorhizal symbioses: Evidence for multiple origins of the symbiotic association. Am. J. Bot. 83:1503 1512.

Trinick, M. J., Goodchild, D. J., and Miller, C. 1989. Localization of bacteria and hemoglobin in root nodules of Parasponia andersoni containing both Bradyrhizobium strains and Rhizobium leguminosarum biovar trifolii. Appl. Environ. Microbiol. 55:2046-2055. 